\section{4. 反応動作における旌形の分析的考察}

宫城教育大学 $\bigcirc$ 海鋒 修, 紊藤 掏三

身体媈動では刺戟反応時間とともに動作目的成就過程 での時閆的空間的変化の様態がその巧否を左右する.こ の研究では以上のことに関して専ら動形分析の立場で追 求した。

被験者の後方または前方から始動合四の音と同時に移 動方向を指示する光信号を発して可及的に急速な適応動 作を起こさせ両側 $75 \mathrm{~cm}$ の地点に設定した直線を含む 唾直面を通過した瞬間をるつて動作成就とした，この動 作を電動式16ミリ・カメラ $(24 / \mathrm{sec})$ で記録し被験者の 頭部，腰部，膝関節，足関節の定部位に付した標識を動 作解析装置によつて追跡し速度と動態を分析した．被験 者は小 2, 4, 6, 中 2, 高 2, 大 2,30〜40 才台主婦，60～ 70 才台老人計 406 名である.

後方信号での動作成就時閆は中 2 が最少值で両側年令 層に移るに従つて增加しその增加率は時間経過に伴つて 順增している．前向きと後向きでの動作成就時間には相 関関保があり，また後向きでの頭部始動時間と前向きで の移動動作開始時間でも高い相関を示すが信号に対する
反纫時間とこれに続く以後の動作成就時間とは函めて低 い相関しかない，以上のことから後向きでの振向き動作 による各部位移動の複雜多様性をさけるため前向き智 をとり大学男女から優 (A) 劣 (B) 二群を 10 名つつ選 んで移動動作開始から踏切足離板までの標㘘移動速度と 動線を比較検討した．その結果次のことが諮められた。 なお今回は問題を腰, 滕, 足に限定した。1. 左右への 急速な移動な構え姿勢でのスタンスが身長の11.0\%以下 では不利である. 2. 踏切時の足関節の伸展方向は水平 軸奇りが有利である. 3. 踏切時点での踏切脚下腿部は 铅直線より移動方向に40度以上内傾し滕前出によるその 前傾は男子で40度，女子で30度前後あれば優位と琭めら れる。つまり楚は始動と同時に急速に前出（前傾）し続 いて強く内旋することが動作成就速度を決定する動形上 の要因といえる，4．掁出脚の膝は同時に始動した腰の その後の動きの誘導性を示しているから下方からやや仰 角の動線になることが必要である。 5，A，B群間に腰， 膝部位の屈折度の有意差はないので明かにみられる動形 の差異は膝の位置によるものであることがわかつた。

\section{5. 力の鱼荷が敏しよう性に及ほすす影翌}

東京教育大学 $\bigcirc$ 金原 勇, 三浦 望薎

小松 邦江

すでに，敏しよう性トレーニンク手段の具備すべき条 件や敏しよう性トレーニンク手段の取り入れ方などつ いて研究し，本学会で発表した．今回は，おすに敏しよ ら性トレーニング手段をつくるにあたつて考慮すべき条 件として力の負荷の影饔を取りあげた。

\section{实験 1. 座位ステッビンクにおける敏しよう性の発} 現と持楼

被験者はかなりトレーニングをつんでいる成人 6名. 5 秒・ 10 秒・ 20 秒・ 40 秒の四つの運動時間で, 最初か ら最後まで文字どらり全力をつくして行なら、いづれの 場合にも最大敏しょう性は，はじめの数秒にあらわれ た.

实験 2. 座位・立位・立位 $30 \mathrm{~kg}$ 角荷てのステツピ ンクにおける敏しよう性の発現と持統

全力で40秒間行なつた．神経の働きが最も優先すると みられるステッピングにおいては，力の負荷が大きくな るにつれて敏しょら性は落ちるが，それぞれの条件での 最大敏しょう性は，はしめの数秒にわたつてあらわれ たまた，敏しょう性の落ち方は力の負荷が大きいはど
著しく，6名の被験者の中で立位では1名，荷重した場 合では 2 名が途中で連動不能になつた（四の $\times \cdots$ 部分か 5).

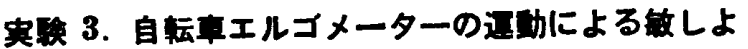 う性の発现と持辚}

笳収縮の巾の大きい，自転車エルゴメーターの運動に よる場合にもいろいろの負荷で実験したが，実験 2 の場 合とほぼ同じょうな結果が得られた。

この研究から，敏しょう性やスピード持久性をねらい とする，負荷条件のちがうトレーニング手段の運動時間 についていくつかの手がかりを得ることができる.

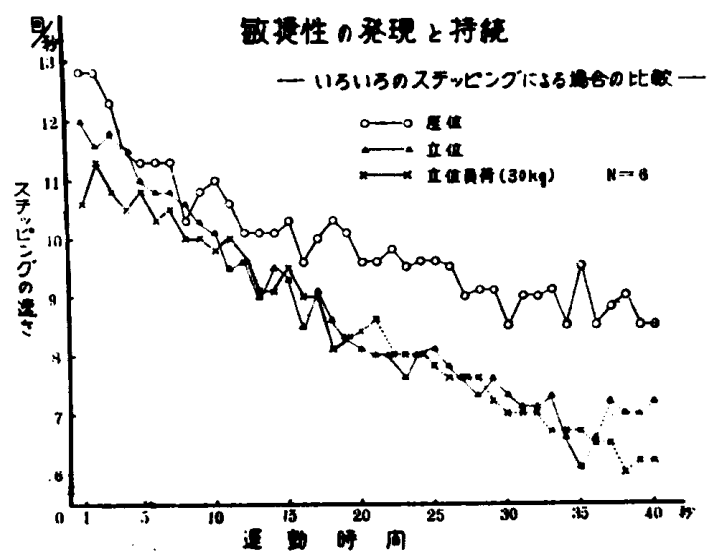

